\title{
The Morphosyntax Of English Deverbal Noun In The Straits Times Website
}

\author{
I Gusti Ayu Indah Maha Dewi $^{{ }^{*} \text {, Yana Qomariana }}{ }^{2}$ \\ ${ }^{[12]}$ English Department, Faculty of Arts, Udayana University \\ [1indahmahadewi28@gmail.com], 2[yqomariana@gmail.com] \\ *Corresponding Author
}

\begin{abstract}
The title of this study is "The Morphosyntax of English Deverbal Noun in The Straits Times Website". This study was conducted in order to find out and analyze the forms and syntactic functions of deverbal noun in The Straits Times website. There were two theories used in this study. The first was the theory proposed by Plag (2002) used to analyze the forms of deverbal noun and the second theory proposed by Quirk (1985) used to analyze the syntactic functions. The data were taken from the lifestyle articles in Straits Times website. The data were collected by documentation method. The collected data were analyzed by using the qualitative method. This study applied formal and informal methods to present the analysis. The result of this study showed that among nominal suffixes forming nouns from verbs stated by Plag, there are seven suffixes found in the data; they are suffix /-age/, /-ance/, /-ant/, /-er/, /-ing/, /-ion/ and /-ment/. Besides, in relation to the syntactic functions, there are four syntactic functions found in the data, they are as part of subject, object, subject complement and object complement functions.
\end{abstract}

\section{Keywords: morphology, deverbal noun, suffix}

\begin{abstract}
Abstrak
Penelitian ini berjudul Morphosyntax of English Deverbal Noun in The Straits Times Website. Penelitian ini dilakukan untuk mengetahui dan menganalisis bentuk dan fungsi sintaksis kata benda deverbal di situs The Straits Times. Ada dua teori yang digunakan dalam penelitian ini. Teori yang pertama adalah teori yang diajukan oleh Plag (2002) yang digunakan untuk menganalisis bentuk kata benda deverbal dan teori kedua yang diajukan oleh Quirk (1985) digunakan untuk menganalisis fungsi sintaksis. Data diambil dari artikel gaya hidup di situs Straits Times. Data dikumpulkan dengan metode dokumentasi. Data yang terkumpul dianalisis dengan metode kualitatif. Penelitian ini menggunakan metode formal dan informal untuk mempresentasikan analisis. Hasil penelitian ini menunjukkan bahwa di antara sufiks nominal yang membentuk kata benda dari kata kerja yang dinyatakan oleh Plag, ada tujuh sufiks yang ditemukan dalam data, yaitu sufiks /-age/, /-ance/, /-ant/, /-er/, /-ing/,/-ion/ and /-ment/. Selain itu, sehubungan dengan fungsi sintaksis, ada empat fungsi sintaksis yang ditemukan dalam data, yaitu sebagai komponen subjek, objek, pelengkap subjek dan fungsi pelengkap objek.
\end{abstract}

Kata kunci: morfologi, kata benda yang berasal dari kata kerja, akhiran

\section{Background of the Study}

Linguistics is the systematic study of the nature, structure, and variation of language. Linguistics has four branches of study; they are phonology, morphology, syntax and semantics.
Morphology is the study of forms of words (Matthews, 1974:1). According to Katamba (1993:3), morphology is the study of the internal structure word. The key element of morphology is the word (Beard, 1995:1). Meanwhile, according 
to Carnie (2011:3), syntax is the study of sentence structure. The combination study of morphology and syntax are called morphosyntax.

A morphological process can be divided into two parts, namely inflectional morphology and derivational morphology. Inflection is the process of attaching affixes without changing the meaning of the word or the word class. On the other hand, derivation is the process of forming a new word by adding an affix. Derivation is concerned with the formation of new lexemes by affixation process. It is the process of forming new words by putting certain morpheme before the base (prefixes), inserting certain morpheme in the middle of the base (infixes), or adding certain morpheme after the base (suffixes). English derivational suffixes are added to the end of a stem. Derivational suffixes usually change the lexical category of the stem, for example, the suffix /-ation/ change a verb 'explore' into a noun 'exploration'. Thus, derivational suffixes can be found in written texts such as newspaper, book and magazine.

News is the information about recent events or happenings, especially as reported by means of newspaper, websites, radio, television, and other forms of media (thefreedictionary.com, 2012). Nowadays, people usually get the information or news through internet. One of the online newspapers that people explore is The Straits Times. The Straits Times is an English-language daily broadsheet newspaper based on Singapore currently owned by Singapore Press Holdings (SPH).

In learning a language, it is necessary to be concerned with a word and the function in the sentence. Various types of words are found in written text such as news. English has four major of word classes; they are nouns, verbs, adjectives and adverbs. Understanding about word classes is important in order to reduce the confusion.

Based on description above, the topic is chosen because it is very interesting to find out the forms and syntactic functions of English deverbal nouns found in some news in The Straits Times website. This current study provides useful information to readers to enhance their understanding of the forms and syntactic functions of deverbal noun suffixes as they help the readers write and understand English sentences.

\section{Problems of the Study}

a) What forms of deverbal nouns are found in The Straits Times website?

b) What are the syntactic functions of deverbal nouns found in The Straits Times website?

\section{Aims of the Study}

a) To find out the forms of deverbal nouns found in The Straits Times website.

b) To explain the syntactic functions of deverbal nouns found in The Straits Times website.

\section{Research Method}

The method used in this study include the following components: data source, method and technique of collecting data, method and technique of analyzing data and method and technique of presenting analysis

\subsection{Data source}

The data in this study were taken from The Straits Times website. The Straits Times is an English-language daily broadsheet newspaper based in Singapore currently owned by Singapore Press Holdings (SPH). The Straits Times is divided into two versions; printed 
version and online version. The online version can be found at www.straitstimes.com. The Straits Times website consists of thirteen rubrics, they are; Singapore, politics, Asia, world, videos, multimedia, lifestyle, food, forum, opinion, business, sport, and technology. However, only the online version that focuses on lifestyle rubric is used as the data source. Thirty articles were taken during 1th-30th September 2017. The reason why Straits Times website was chosen as the data source because there were sufficient data related to this study and also the news in this website are always renewed quickly.

\subsection{Method and technique of collecting data}

The method of collecting data in this study is documentation method and note taking techniques. In collecting the data there are some techniques; first, accessing the website of The Straits Times at www.straitstimes.com. Second reading the lifestyle articles which had been selected in The Straits Times website intensively. Third, the sentences containing deverbal nouns in the articles were noted. Lastly, the collected data were classified based on their suffixes and were highlighted.

\subsection{Method and Technique of Analyzing Data.}

The collected data were analyzed by qualitative method. Qualitative method only focuses on various non-numeral data. The data of this study were analyzed by the following techniques:

1. The data were analyzed according to the forms of suffixes attached to words and separated from each suffix to find out the word bases and the morphological process using the theory of Word-formation in English proposed by Plag (2002:109-116).
2. The selected data were analyzed to find out the syntactic function of deverbal nouns using the theory proposed by Quirk et al (1985:38-39) entitled A Comprehensive Grammar of The English Language.

\subsection{Method and Technique of Presenting Data}

The analysis of this study was presented both in formal and informal methods. Formal method is a method in which the findings were presented by using symbols, diagrams, figures, and tables, while informal method refers to the method of presenting the analyzed data using words. In presenting the data, the technique chosen was a tree diagram and the data were also explained descriptively.

In presenting data, several steps were taken. First, the analysis was divided according to the forms of suffixes. The second step was listing the number and presenting each of deverbal noun suffixes into a tree diagram in order to explain the morphological process. The next step was classifying the constituent of the sentence and presenting the sentences into a tree diagram in order to find out the syntactic function. Below the diagrams, the number, the deverbal noun, and the sentence where the deverbal noun and the function found were given. Lastly, the discussion and result were elaborated in the form of paragraph. The important words were presented in bold and italic.

\section{Result and discussion}

\subsection{Forms and syntactic functions of Deverbal Noun}

According to the theory proposed by Plag (2002:109-116), there are ten forms of suffixes forming nouns from verbs, they are /-age/, /-al/,/-ance/, /-ant /, /-ee/, /-(e)ry/, /-er/, /-ing/, /-ion/, /-ment/. 
However, not all the forms of deverbal nouns were found in the data source. There were seven forms of derivational suffix forming noun from verb that can be found in the data. Then, the analysis is followed by the analysis of syntactic functions of deverbal noun. The data were analyzed using a tree diagram proposed by theory from Quirk et al (1985:38-39). The syntactic functions of deverbal noun are classified into four; they are as the part of subject, object, subject complement and object complement. Based on the analysis in this study, all functions were found in the data. The analyses are presented below:

\subsubsection{Suffix /-age/}

The form /-age/ is a derivative suffix. This suffix derives nouns that express an activity or result (Plag, 2002:109). Based on explanation above, there is one word which can be categorized as -age form found on the data source.

1. He has two children from a previous marriage. (2.2017)

In the sentence above, the word marriage is a deverbal noun. It can be shown by the morphological process as follows:

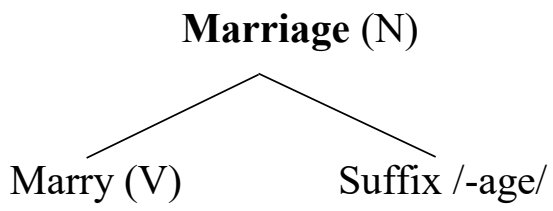

Marry $(\mathrm{V})+$ suffix /-age/ = marriage $(\mathrm{N})$

In example (1), the word marriage is a noun class. The word marriage is formed undergoing a derivational process. The word marry ended by $/ y /$; however, after undergoing a morphological process, the consonant $/ y /$ is changed into the vowel $/ \mathrm{i} /$. The word marriage comes from a free morpheme marry as the base and a bound morpheme -age as the nominal suffix that produces a new word marriage. As a verb, marry means to become a legally accepted husband or wife of someone in an official or religious ceremony. The additional suffix -age at the end of the word marry is changing the word class from verb (marry) into noun (marriage). As a noun, marriage means a legally accepted relationship between two people in which they live together.

In sentence (1), the word marriage is a part of object complement. The word marriage belongs to a noun category. The noun phrase 'a previous marriage' is an object complement, formed of determiner 'a', adjective 'previous' as modifier that modifies the head and noun 'marriage' as the head of the phrase. The noun phrase 'a previous marriage' appears after the preposition 'from' in a sentence. Thus, the NP 'a previous marriage' is the object of the preposition 'from'.

The tree diagram of the sentence (1) can be illustrated as follows:

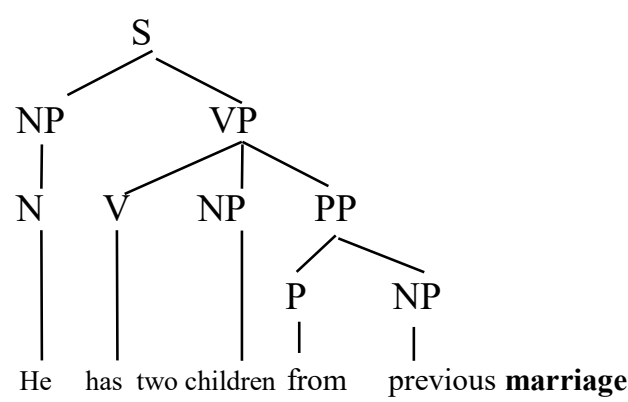

\subsubsection{Suffix /-ance/}

The attachment of suffix /-ance/ changes the word class from a verb into a noun. The presence of the suffix /-ance/ is to indicate the action or state of (Plag, 2002:110). Based on the explanation above, there are two words which can be categorized as -ance forms found on the data source.

2. The broadcast will include music performances. (5.2017) 
The word typed in bold is deverbal noun. The morphological process for data number 2 is shown as follows:

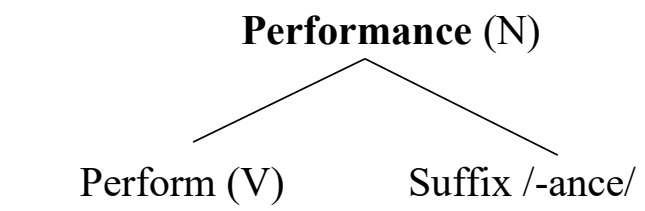

Perform (V) + suffix /-ance/ = performance $(\mathrm{N})$

The word 'performances' above is in a plural form. In this case, the analysis is only focused on derivational process. Therefore with or without /-s/ has no relation in class changing process. The word performance can be determined as a noun according to Cambridge dictionary. The word performance is derived from a verb (perform) + (-ance). As a verb, perform means to do an action or piece of work. The attachment suffix -ance in the word performance is changing the class of word from a verb into a noun. As a noun, performance means the action of entertaining other people by dancing, singing, acting, or playing music

In sentence (2), the word performances is a part of object. The word performances belongs to a noun class. The nouns phrase 'music performances' is an object, formed of noun 'music' and noun 'performances'. The phrase is headed by noun 'performances'; therefore, it becomes noun phrase. The NP 'music performances' appears after a verb phrase 'will include'. Thus, the NP 'music performances' is the object of the verb.

The tree diagram of sentence (2) can be illustrated as follows:

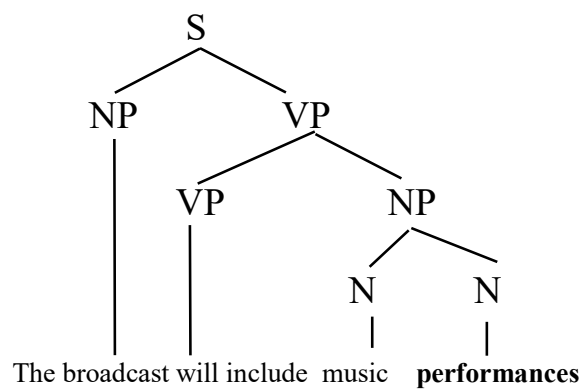

\subsubsection{Suffix /-ant/}

This suffix forms count nouns referring to persons (often in technical or legal discourse). Most bases are verbs of Latinate origin (Plag, 2002: 110). Based on the explanation above, there is one word which can be categorized as -ant form found on the data source. The data are shown in the following example:

3 . The contestants hailed from 13 countries. (29.2017)

In the sentence above, the word contestants is a deverbal noun. It can be shown by the morphological process as follows:

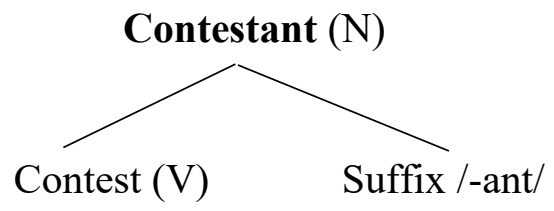

Contest $(\mathrm{V})+$ suffix $/$-ant $/=$ contestant (N)

The word 'contestants' above is in a plural form. In this case, the analysis is only focused on derivational process. Therefore, with or without /-s/ it has no relation in class changing process. The word contestant can be determined as a noun according to Cambridge dictionary. The word contestant is derived from (contest) $+($-ant $)$. The base of the word contestant is contest which belongs to a verb. As a verb, contest means to engage in competition to attain a position. The attachment of suffix /-ant/ changes the word class from a verb into a noun. As a 
noun, contestant means someone who competes in a contest.

In the sentence (3), the word contestants is a part of subject. The word contestants belongs to noun class. The noun phrase 'the contestants' functions as subject, formed of determiner 'the' and noun 'contestants'. The phrase is headed by noun 'contestants'; therefore, it becomes noun phrase. The NP 'the contestants' appears before the verb 'hailed' of the sentence.

The tree diagram of the sentence (3) can be illustrated as follows:

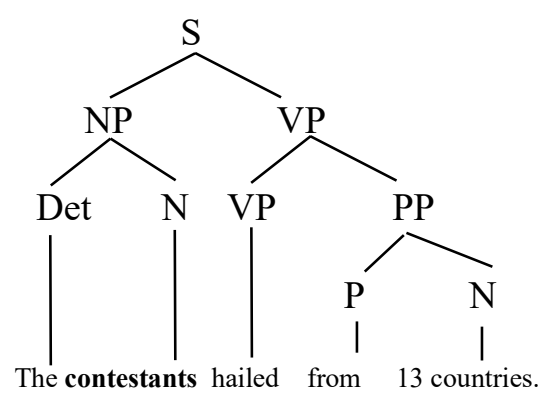

\subsubsection{Suffix /-er/}

The attachment of suffix /-er/ changes the word class from a verb into a noun. The meaning of this suffix is to signify a person or entity that is active or a volitional participant in an event. The orthographic variant/-or/ occurs mainly with Latinate bases ending in /s/ (Plag, 2002:112). Based on the explanation above, there are six words which can be categorized as -er form found on the data source.

4. The singer boots her new-found style. (4.2017)

In the data number 4, the word singer is a deverbal noun. It can be shown by the morphological process as follows:

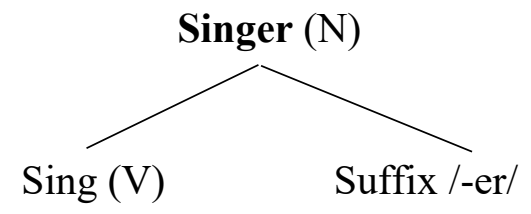

Sing $(V)+$ suffix $/$-er/ $=\operatorname{singer}(\mathrm{N})$
In the example above, the word singer is a verb according to Cambridge dictionary. The word singer is derived from (sing) + (-er). The word singer comes from a free morpheme sing as the base and it belongs to a verb, added with a bound morpheme /-er/ as deverbal noun that produces a new word singer. As a verb, sing means to make musical sounds with the voice. The attachment of suffix /-er/ changes the word class from a verb into a noun. As a noun, singer means a person who sings

In sentence (6), the word singer is a part of subject. The word singer belongs to a noun class. The noun phrase 'the singer' formed of a determiner 'the' and a noun 'singer' as the head of the phrase and determiner 'the' modifies the head as pre-modifier. The NP 'the singer' appears before the verb 'boots' of the sentence.

The tree diagram of the sentence (4) can be illustrated as follows:

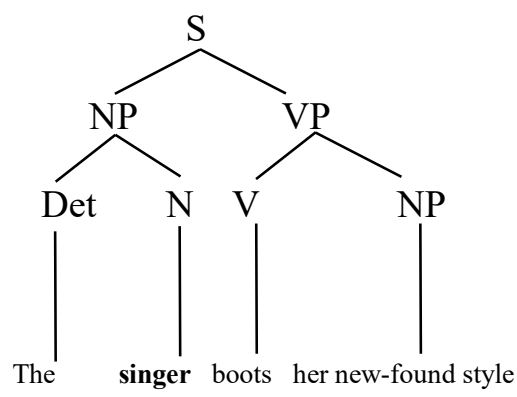

\subsubsection{Suffix /-ing/}

The attachment of suffix /-ing/ can change the word class from a verb into a noun. It denotes the activity, process or result (Plag, 2002:114). Based on explanation above, there are four words which can be categorized as -ing form found on the data source.

5. Filming has already wrapped for Crazy Rich Asians. (7.2017)

The word typed in bold is deverbal noun. The morphological process for data number 5 is shown as follows: 


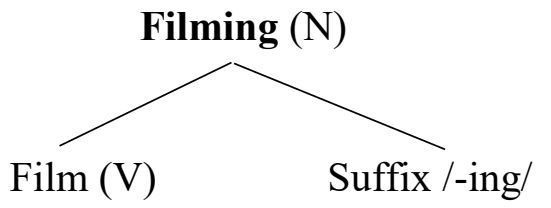

Film (V) + suffix /-ing/ = filming (N)

The word filming is a noun class according to Cambridge dictionary. The word filming is a deverbal noun which is derived from a verb film. As a verb, film means to record moving pictures with a camera, usually to make a film for television or the cinema. The attachment of suffix /-ing/ changed the form from a verb into a noun. As a noun filming means the activity of making a film

The word filming belongs to a noun category. The word filming functions as a subject. The word 'filming' appears before the verb phrase 'has already wrapped' of the sentence. Thus, the word 'filming' is the subject of the verb phrase 'has already wrapped'. The tree diagram of the sentence (5) can be illustrated as follows:

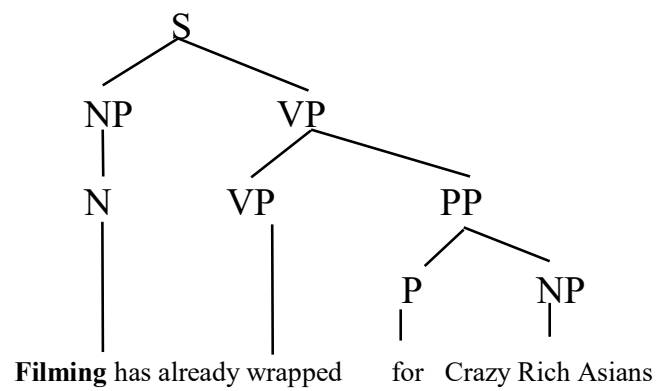

\subsubsection{Suffix /-ion/}

The attachment of the suffix /ion/ changes the word class from a verb into a noun. This /-ion/ suffix denotes events or results of processes. (Plag, 2002:114). Based on explanation above, there are six words which can be categorized as -ion form found on the data source.
6. It feels like a Manichean construction. (20.2017)
In data number 6, the word construction is a deverbal noun. It can be

shown by the morphological process as follows:

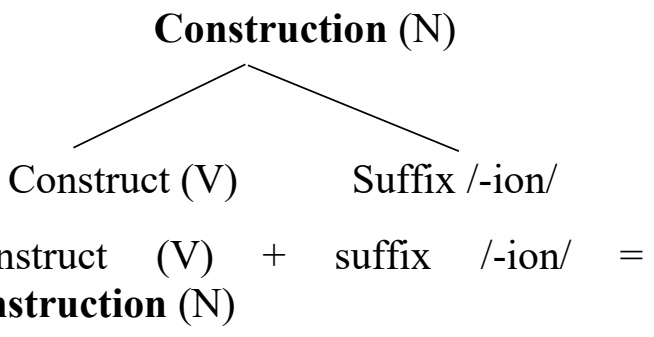

In the example above, the word construction is a noun class according to Cambridge dictionary. The word construction is derived from (construct) + (-ion). The word construction comes from a free morpheme construct as the base and it belongs to a verb, added with a bound morpheme /-ion/ as deverbal noun that produces a new word construction. As a verb, construct means to build something or put together different parts to form something whole. The attachment of suffix /-ion/ changes the word class from a verb into a noun. As a noun, construction means a building or other structure.

The word construction is a part of subject complement. It belongs to a noun category. In sentence (16), the word 'construction' is the head of the noun phrase 'a Manichean construction' which functions as a subject complement. The NP 'a Manichean construction' appears after the linking verb 'feels' and receives no action from the verb. Thus, the NP ' $\mathrm{a}$ Manichean construction' is the complement of the verb 'feels'.

The tree diagram of sentence (6) can be illustrated as follows:

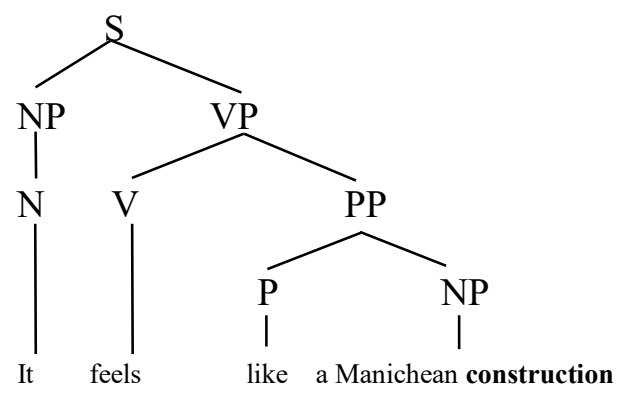




\subsubsection{Suffix /-ment/}

The attachment of the suffix /-ment/ changes the word class from a verb into a noun. This suffix derives action nouns denoting processes or results from verbs. (Plag, 2002:116). Based on explanation above, there are four words which can be categorized as -ment form found on the data source.

7. She went to a hair treatment clinic. (21.2017)

The word typed in bold is deverbal noun. The morphological process of data number 21 can be shown as follows:

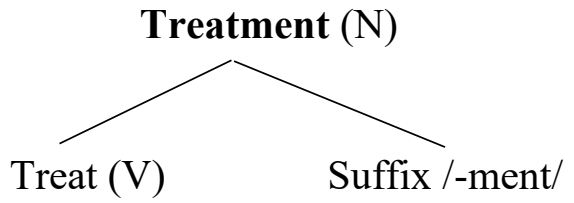

Treat $(\mathrm{V})+$ suffix $/$-ment $/=$ treatment (N)

In example (7), the word treatment is a noun class according to Cambridge dictionary. The word treatment comes from a free morpheme treat as the base and it belongs to a verb, added with a bound morpheme /-ment/ as the nominal suffix that produces a new word treatment. As a verb, treat means to behave towards someone in a particular way. The attachment of suffix /-ment/ changes the word class from a verb into a noun. As a noun, treatment means the attachment of suffix /-ion/ changes the form from a verb into a noun. As a noun, investigation the use of exercises

The word treatment is a part of object complement. It belongs to a noun category. The noun phrase 'a hair treatment clinic' consists of determiner 'a', noun 'hair', noun 'treatment' as modifier that modifies the noun 'clinic' as the head of the NP. The noun phrase 'a hair treatment clinic' appears after a preposition 'to' in a sentence.
The tree diagram of sentence (7) can be illustrated as follows:

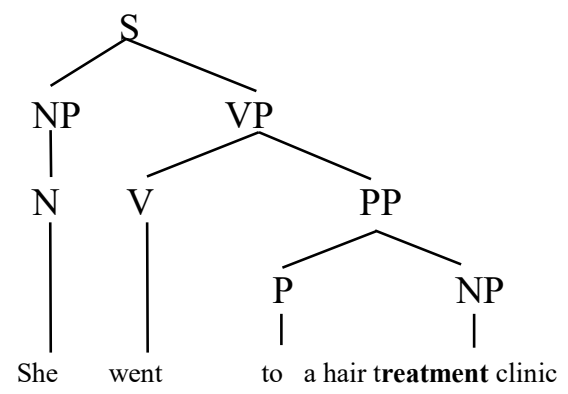

\section{Conclusions}

From the analysis written in the previous chapter, it can be concluded that there are 80 words of deverbal noun found in thirty articles in the website 'straitstime.com' in the lifestyle rubric. Based on this study, there were only seven suffixes found in the data, those are suffix /-age/, /-ance/, /-ant/, /-er/, /ing/, /-ion/, and /-ment. The suffixes /-al/, /-(e)ry/, and /-ee/ were not found. There are one of suffix /-age/, five of suffixes /ance/, three of suffixes /-ant/, twenty two of suffixes /-er/, eleven of suffixes /-ing/, twenty one of suffixes /-ion/, and seventeen of suffixes /-ment/. Out of all suffixes, /-er/ suffix is the most frequently appeared in the data.

The second analysis presents a tree diagram of each data in order to show the syntactic function. In terms of the syntactic functions of deverbal noun, all functions were found in the data, those are as part subject, object, subject complement, and object complement. The analysis shows that the data contains twenty two of deverbal nouns which belongs to the function as part of a subject, twenty one of deverbal nouns which belongs to the function as part of an object, thirteen of deverbal nouns which is belongs to the function as part of a subject complement and twenty four of deverbal nouns which belongs to the function as part of an object complement. It shows that the syntactic function of deverbal noun as part of object 
complement appears very intense than other functions.

\section{Refrences}

Quirk, R., et al., 1985. A Comprehensive Grammar of the English Language. New York: Longman, United Kingdom.

Plag, Ingo., 2002. Word Formation in English. Cambridge: Cambridge University Press, United Kingdom.

The Straits Times [Internet]. Available from:http:www.straitstimes.co $\underline{\mathrm{m}}$. [accessed on September 2017]. 